\title{
Gastrointestinal Stromal Tumor Clinical TNM Finding v7
}

National Cancer Institute

\section{Source}

National Cancer Institute. Gastrointestinal Stromal Tumor Clinical TNM Finding v7. NCI

Thesaurus. Code C90058.

A clinical finding about one or more characteristics of gastrointestinal stromal tumor, following the rules of the TNM AJCC V7 classification system. 